\title{
E-Commerce Adoption
}

GSLC 4

Oleh

Louis Beverly - 2101714585

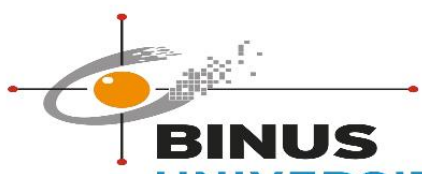

UNIVERSITY

Management

ISY8175005 - E-Business Strategy and Implementation - TB21 - 2110

UNIVERSITAS BINA NUSANTARA

ALAM SUTERA 


\begin{abstract}
Abstrak
IDN Times (2017) mencatat bahwa lima perusahaan e-commerce yang memiliki audience besar mengalami pertumbuhan rata-rata luar biasa sebesar 97\%. Matahari Mall memegang nilai pertumbuhan tertinggi sebesar 201\%, disusul oleh JD.id sebesar $135 \%$ dan Blibli sebesar $107 \%$. Jumlah perusahaan yang mengadopsi teknologi di Indonesia mencapai 26,6 juta hingga tahun 2017. E-commerce menghadirkan prospek yang berbeda bagi Usaha Kecil Menengah (UKM) dan memberikan keuntungan bagi UKM. Ada sejumlah peluang yang dirasakan oleh adopsi e-commerce di Indonesia, yaitu memperluas jangkauan pasar bahkan global, meningkatkan layanan personalisasi pelanggan, dan meningkatkan daya saingnya. Adapun enam faktor potensial yang mempengaruhi adopsi e-commerce oleh UKM di Indonesia, yaitu persepsi kegunaan, persepsi kemudahan penggunaan, keuntungan relatif, persepsi risiko, persepsi kepercayaan, dan kompatibilitas.
\end{abstract}

\title{
1. Pendahuluan
}

Pesatnya perkembangan teknologi mengakibatkan persaingan di bidang bisnis tidak dapat dihindari, sehingga perusahaan perlu mengetahui langkah-langkah yang tepat agar tetap bertahan dan mampu bersaing dengan perusahaan lain yang sejenis. Salah satu langkah yang dapat dilakukan perusahaan adalah dengan menerapkan teknologi pada proses bisnisnya. Teknologi sudah menjadi kebutuhan masyarakat. Penerapan teknologi diharapkan dapat mempermudah, mempercepat proses transaksi, menghemat biaya, waktu, tenaga dan dapat menjangkau pasar yang lebih luas. Turban et al (2012), membagi keuntungan penerapan elektronik atau teknologi dalam proses bisnis menjadi dua, bagi perusahaan dan pelanggan. Manfaat bagi perusahaan adalah memperluas jangkauan pasar baik ke pasar nasional maupun internasional, mengurangi biaya pemrosesan, distribusi dan penarikan informasi yang akurat dan real-time. Sedangkan keuntungan bagi pelanggan seperti akses 24 jam ke sejumlah besar barang dan jasa. Liputan6.com (2018), mencatat perkembangan e-commerce sebesar 26,2 juta dan Alibaba merupakan perusahaan e-commerce terbesar untuk saat ini. Badan Pusat Statistik (BPS) mencatat telah terjadi peningkatan jumlah perusahaan yang menerapkan $e$-Commerce di Indonesia dalam 10 tahun terakhir tumbuh menjadi sekitar 17. Detik.com (2015), mencatat bahwa Indonesia telah menjadi e-commerce terbesar pada pasar perdagangan di seluruh Asia Tenggara. Pada 2014, Euromonitor mencatat penjualan online Indonesia mencapai US\$ 1,1 miliar, lebih tinggi dibandingkan Thailand dan Singapura. Dengan demikian, pasar $e$ commerce Indonesia berpeluang tumbuh lebih besar lagi dengan jumlah penduduk terbesar dan tingkat Produk Domestik Bruto (PDB) terbesar di ASEAN. Euromonitor memperkirakan rata-rata pertumbuhan tahunan penjualan online di Indonesia selama 2014-2017 adalah 38\%. Menurut Turban et al (2012); Shahriari \& Gheiji (2015), mendefinisikan $e$-commerce sebagai segala upaya dan proses penjualan barang atau jasa dengan mengadopsi teknologi sebagai sarananya [1].

E-commerce dapat bermanfaat bagi organisasi dari semua ukuran, terutama untuk sektor usaha kecil. UKM memainkan peran penting dalam mengurangi tingkat kemiskinan dan pengangguran dalam perekonomian Indonesia. E-commerce dapat memperkenalkan peluang yang berbeda untuk UKM dan dapat membantu sektor ini dalam menangani berbagai teknologi dan organisasi yang tidak memadai. UKM dapat menggunakan teknologi e-commerce untuk berinteraksi dengan pelanggan dan pemasok, mengumpulkan data riset pasar, mengiklankan barang dan jasa, menyediakan informasi 
yang luas dan berorientasi pengguna tentang barang dan jasa, menyediakan transaksi online, serta dukungan dan bantuan purna jual. Selain itu, penelitian sebelumnya juga menunjukkan bahwa UKM dapat memanfaatkan teknologi e-commerce dalam meningkatkan usahanya. Dengan demikian, penggunaan teknologi e-commerce memungkinkan UKM untuk meningkatkan efisiensi dan posisi kompetitif mereka di pasar. Posisi UKM di negara berkembang dalam hal adopsi $e$-commerce bahkan tertinggal dari UKM di negara maju [2].

\section{E-Commerce}

E-Commerce adalah sebuah konsep yang telah mengubah alur kehidupan manusia. E-Commerce juga dapat dikatakan sebagai tolak ukur utama dari revolusi teknologi informasi dan komunikasi, khususnya di bidang ekonomi. Pernyataan tersebut didukung oleh Shahriari \& Gheiji (2015), yang mengatakan e-commerce adalah suatu proses pertukaran atau jasa dengan menggunakan jaringan internet [1].

Electronic commerce (e-commerce) adalah proses pembelian, penjualan, pemindahan atau pertukaran produk, jasa dan/atau informasi melalui jaringan komputer, termasuk internet. Ini berkaitan dengan bagaimana TI digunakan oleh suatu organisasi untuk meningkatkan kualitas interaksi dengan dan antara semua pemangku kepentingannya. E-commerce memberikan manfaat bagi organisasi, pelanggan individu dan masyarakat. Beberapa manfaat e-commerce adalah jangkauan global, pengurangan biaya, , waktu ke pasar yang cepat, peningkatan kecepatan, layanan pelanggan yang ditingkatkan, ketersediaan informasi yang ditingkatkan, keputusan bisnis yang tepat waktu, dan kurang pentingnya geografi. Hal ini dapat membawa keuntungan perusahaan melalui manfaat tersebut di atas yang pada akhirnya memperluas penetrasi pasar, operasi yang optimal, dan pada akhirnya meningkatkan pendapatan melalui implementasi berkelanjutan yang cermat dan selektif di perusahaan [2].

\section{Usaha Kecil dan Menengah (UKM)}

Usaha Kecil dan Menengah (UKM) adalah organisasi bisnis yang skalanya sangat kecil, yang seringkali merupakan perusahaan keluarga dan kurangnya jaringan. Lembaga keuangan cenderung mengabaikan potensi keuangan mereka karena aset mereka yang tidak memadai. Faktanya, pengalaman menunjukkan bahwa UKM adalah jenis perusahaan yang memiliki sistem kekebalan terkuat terhadap turbulensi keuangan global dan pertumbuhan paling cepat. Ekonom percaya bahwa mereka adalah salah satu lubang dan pilar yang kuat untuk pengembangan industri dan mendorong pertumbuhan ekonomi nasional dan daerah. Dengan demikian, UKM lebih mudah beradaptasi dan elastis dibandingkan dengan perusahaan mereka yang relatif lebih besar ketika menghadapi perubahan pasar atau turbulensi ekonomi global. Mereka relatif lebih cepat dalam mengadopsi peluang inovasi dan perubahan strategi pasar. Mereka memiliki kemampuan untuk segera mengenali perubahan lingkungan meskipun mereka memiliki sumber daya yang tidak mencukupi. Itulah faktor-faktor kunci yang memastikan posisi strategis mereka dalam mendorong pembangunan ekonomi [2].

UKM di Indonesia didefinisikan sebagai usaha produktif yang berdiri sendiri, yang dijalankan oleh orang perseorangan atau perusahaan yang bukan merupakan anak perusahaan yang dimiliki, dijalankan atau menjadi bagian baik langsung maupun tidak langsung dari suatu perusahaan besar. Menurut UU No.20 Tahun 2008, Usaha Kecil memiliki kriteria sebagai berikut: (1) kekayaannya antara 50.000.000 sampai dengan 500.000.000 (IDR) termasuk tanah dan bangunan, dan (2) penjualan tahunannya antara 
300.000. 000 dan 2.500.000.000 (Rp). Usaha Menengah memiliki kriteria sebagai berikut: (1) asetnya antara 500.000.000 sampai dengan 10.000.000.000 (IDR) termasuk tanah dan bangunan, dan (2) penjualan tahunannya antara 2.500.000.000 sampai dengan 50.000.000.000 ( Rp). Lebih lanjut, Badan Pusat Statistik (BPS) Indonesia memberikan definisi UKM berdasarkan jumlah tenaga kerja, yaitu 5-19 orang untuk usaha kecil dan 20-99 orang untuk usaha menengah [2].

\section{Adopsi E-Commerce Di Indonesia}

Beberapa penelitian terkait dengan adopsi e-commerce di Indonesia telah dilakukan. Vidi menemukan bahwa kompatibilitas, dukungan manajemen puncak, kesiapan organisasi, tekanan eksternal, dan manfaat yang dirasakan berpengaruh positif signifikan terhadap adopsi E-commerce, dan adopsi berpengaruh positif signifikan terhadap kinerja perusahaan. Ia menggunakan Technology Acceptance Model (TAM) untuk membuat model adopsi e-commerce yang diterapkan pada UKM di Indonesia. Data dikumpulkan dari sembilan kota besar di Indonesia, yaitu Padang, Jakarta, Cirebon, Yogyakarta, Jepara, Sidoarjo, Denpasar, Makassar, dan Balikpapan. Hafied mencatat bahwa UKM sudah mulai menerapkan adopsi e-commerce untuk mempertahankan proses bisnis mereka. Meskipun tingkat adopsi berbeda antara satu UKM dengan UKM lainnya, namun secara umum masih diterima bahwa adopsi $e$-commerce akan membawa dampak positif bagi perkembangan UKM. Dia juga menemukan bahwa pembiayaan dan layanan pelanggan adalah faktor pendorong utama dalam mengadopsi $e$-commerce [2].

Praktisi UKM memandang bahwa penerapan e-commerce untuk mendukung operasional perusahaan cukup bermanfaat, terutama dalam proses, seperti pemasaran produk, penanganan persediaan produk, proses manufaktur, hingga pengadaan material. Meskipun implementasi e-commerce dapat mendukung perkembangan pemasaran produk UKM, namun dalam pelaksanaannya tidak selalu berjalan mulus. Pengguna menemukan sejumlah kendala, seperti akses internet yang memakan waktu lama, sulit untuk beralih ke teknologi berbasis transaksi, dan perusahaan secara tradisional lebih suka bertransaksi. Secara umum, UKM sulit untuk berubah dari pembelian tradisional, yaitu transaksi yang dilakukan secara fisik, menjadi pembelian berbasis teknologi. Mereka menganggapnya sebagai kendala tertinggi untuk adopsi e-commerce. Govindaraju dan Chandra menemukan bahwa secara umum UKM di Indonesia yang berpartisipasi dalam penelitian ini memiliki rencana strategis untuk mengadopsi tingkat e-commerce yang lebih tinggi, meskipun sebagian besar perusahaan saat ini masih mengadopsi e-commerce di tingkat yang lebih rendah. Ada tiga faktor signifikan sebagai hambatan adopsi ecommerce di UKM Indonesia. Mereka adalah kekuatan pendorong dari lingkungan internal dan eksternal, manusia dari lingkungan internal, dan sumber informasi dari lingkungan eksternal [2].

Berdasarkan tinjauan literatur di atas, dapat dijelaskan bahwa faktor-faktor yang mempengaruhi adopsi e-commerce oleh UKM di Indonesia, terdiri dari enam faktor adalah manfaat yang dirasakan, kemudahan penggunaan yang dirasakan, keuntungan relatif, risiko yang dirasakan, kepercayaan yang dirasakan, kompatibilitas.

\section{Kesimpulan}

UKM dapat memanfaatkan teknologi e-commerce dalam mengembangkan usahanya. Dengan demikian, penggunaan teknologi e-commerce memungkinkan UKM untuk meningkatkan efisiensi dan posisi kompetitif mereka di pasar. Berdasarkan studi literatur tentang adopsi e-commerce, ditemukan bahwa ada beberapa peluang yang 
dirasakan oleh adopsi e-commerce di Indonesia yaitu memperluas jangkauan pasar dan bahkan global, meningkatkan layanan personalisasi pelanggan, dan meningkatkan daya saingnya. Selanjutnya, ditunjukkan enam faktor potensial yang mempengaruhi adopsi $e$ commerce oleh UKM di Indonesia, yaitu manfaat yang dirasakan, kemudahan penggunaan yang dirasakan, keuntungan relatif, risiko yang dirasakan, kepercayaan yang dirasakan, dan kompatibilitas.

\section{Referensi:}

[1] Lasmy, Saroso, H., Syahchari, D. H., Sudrajat, D., \& Herlina, M. G. (2019). EService Quality And Corporate Image On Customer Perception. International Journal of Innovation, Creativity and Change, 10 (8), 284-294

[2] Triandini, Evi., Djunaidy, Arif., Siahaan, Daniel. (2013). Factors Influencing ECommerce Adoption by SMES Indonesia: A Conceptual Model. Lontar Komputer Vol. 4, No. 3. 